\title{
ACTIVITY OF DISINFECTANTS AGAINST FOODBORNE PATHOGENS IN SUSPENSION AND ADHERED TO STAINLESS STEEL SURFACES
}

\author{
Tatiane Karen Cabeça*, Antonio Carlos Pizzolitto, Elisabeth Loshchagin Pizzolitto*
}

Universidade Estadual Paulista, Faculdade de Ciências Farmacêuticas, Araraquara, Sao Paulo, Brasil.

Submitted: September 02, 2009; Returned to authors for corrections: April 04, 2010; Approved: June 07, 2012.

\begin{abstract}
The purpose of this study was to investigate and compare the efficacy of various disinfectants on planktonic cells and biofilm cells of Listeria monocytogenes, Staphylococcus aureus and Escherichia coli. Numbers of viable biofilm cells decreased after treatment with all tested disinfectants (iodine, biguanide, quaternary ammonium compounds, peracetic acid and sodium hypochlorite). Sodium hypochlorite was the most effective disinfectant against biofilm cells, while biguanide was the least effective. Scanning electron microscopy observations revealed that cells adhered on stainless steel surface after treatment with the disinfectants. No viable planktonic cells were observed after treatment with the same disinfectants. Based on our findings, we concluded that biofilm cells might be more resistant to disinfectants than plancktonic cells.
\end{abstract}

Key words: biofilm cells, plancktonic cells, disinfectants.

\section{INTRODUCTION}

Microorganisms were shown to form biofilms on the surface of materials commonly used in food processing, such as stainless steel $(3,31)$; thus, these surfaces become potential source of contamination that may lead to food spoilage, transmission of diseases $(19,27,31)$, equipment damage and compromise the sanitation of food surfaces and environmental surfaces by spreading detached organisms to other areas of processing plants (29). Biofilm formation may be separated into the primary attachment of bacteria to surfaces, followed by proliferation of the attached bacterial cells, which leads to the accumulation of multilayered clusters of cells and extracellular polymer (glycocalyx) formation $(6,10)$. Biofilm bacteria can be physically and morphologically different from their planktonic counterparts, especially in response to sanitizers and biocides $(8,17,20,29,31)$.

It is well documented that bacteria, including foodborne pathogens such as Listeria monocytogenes, Staphylococcus aureus and Escherichia coli, can 'stick' to a variety of surfaces found in food industries $(5,14,19,2428)$. To reduce or eliminate microorganisms on food contact surfaces, food processors have relied on techniques that have been proven over many years of use. These techniques include physical methods (e.g. hand washing, high pressure sprays) and chemical methods (e.g. hypochlorites, iodophores, quaternary ammonium compounds). Both techniques should remove and inactivate microorganisms that might be on the surface of equipment which may eventually come in contact with raw and processed food $(4,5,14)$.

\footnotetext{
*Corresponding Author. Mailing address: Rua Expedicionários do Brasil, 1621, CEP: 14801-902,SP, Brasil.; Tel.: (+5516) 3301 6107.; E-mail: taticabeca@yahoo.com.br/pizzolel@fcfar.unesp.br
} 
Even with the use of chemical cleaning agents and acceptable clean-in-place (CIP) systems, bacteria can remain on equipment and surfaces used in the food industry. These organisms may survive for prolonged periods, depending on the amount and nature of residual soil, temperature, and relative humidity $(8,31)$.

The goal of this study was to compare the effects of various disinfectants on planktonic cells in suspension and on biofilm cells of Listeria monocytogenes, Staphylococcus aureus and Escherichia coli.

\section{MATERIALS AND METHODS}

\section{Bacterial strains}

The following strains of bacteria were used in this study: Listeria monocytogenes ATCC 7644, Staphylococcus aureus ATCC 6538 and Escherichia coli ATCC 25922. All strains were obtained from the National Institute of Quality Control in Health - Oswaldo Cruz Foundation (FIOCRUZ; Rio de Janeiro, Brazil).

\section{Preparation of suspension}

The bacterial strains were grown overnight (18 to $24 \mathrm{~h}$ ) at $37^{\circ} \mathrm{C}$ with shaking (150 revolutions per minute-rpm) in tryptic soy broth (DIFCO). Cells were harvested by centrifugation at $5,000 \times \mathrm{g}$ for $3.5 \mathrm{~min}$ and washed three times in phosphatebuffered saline (PBS; 0.1M, pH 7.2). Cell pellets were resuspended in PBS and adjusted by a spectrophotometer to an A660 of approximately 0.5 , corresponding to $\sim 10^{8} \mathrm{CFU} / \mathrm{ml}$ (21).

\section{Disinfectants}

The disinfectants used in this study were chosen to represent those used in the food industry. The following disinfectants were used: iodine $(0.20 \% \mathrm{w} / \mathrm{v})$, biguanide $(0.50 \%$ $\mathrm{w} / \mathrm{v})$, quaternary ammonium compounds $(0.50 \% \quad \mathrm{w} / \mathrm{v})$, peracetic acid $(0.50 \% \mathrm{w} / \mathrm{v})$ and sodium hypochlorite $(1.50 \%$ $\mathrm{w} / \mathrm{v})$. All the disinfectants used were provided by Johnson-
Diverseylever, Brazil. These agents were diluted with sterilized distilled water according to the manufacturer's instructions.

\section{Test surface}

AISI type 304 stainless steel was the surface chosen as it is used extensively throughout the food processing industry. Flat, stainless steel coupons $(1 \mathrm{x} 1 \mathrm{~cm})$ were used as the test surface to examine biofilm formation in vitro. The coupons were initially soaked overnight in acetone to remove grease. After soaking, the steel coupons were placed in a sterile tube and sonicated for $15 \mathrm{~min}$ in a bath sonicator. The coupons were then washed in tap water followed by three washes with distilled water, and they were autoclaved at $121^{\circ} \mathrm{C}$ for $15 \mathrm{~min}$ (23). The manipulations of coupons were assisted with a sterile surgical clamp for all assays.

\section{Biofilm formation in vitro}

A $20 \mu \mathrm{l}$ aliquot of the $10^{8} \mathrm{CFU} / \mathrm{mL}$ suspension prepared as described above was placed in $50 \mathrm{~mL}$ plypropylene tubes (9) containing $15 \mathrm{~mL}$ of inoculated Mueller Hinton Broth (11) and one sterilized stainless steel coupon, and incubated at $37^{\circ} \mathrm{C}$ under constant agitation of $100 \mathrm{rpm}$ for 5 days. The culture medium was changed every 3 days. Biofilm formation was confirmed using scanning electron microscopy (25).

\section{Activities of the tested disinfectants against the biofilm cells}

After biofilm formation, coupons were rinsed twice with 5 $\mathrm{mL}$ of sterile physiological saline to remove any attached bacterial cells, and separately placed in Petri dishes containing $20 \mathrm{~mL}$ of one of the tested disinfectants at $25 \pm 2^{\circ} \mathrm{C}$ for $10 \mathrm{~min}$. A positive control was performed by placing a coupon in a Petri dish containing $20 \mathrm{~mL}$ of sterile physiological saline. The coupons were removed from the dishes and immediately transferred to $5 \mathrm{~mL}$ of Letheen Broth (11) for $10 \mathrm{~min}$ to inactive the disinfectants and rinsed twice again with $5 \mathrm{~mL}$ of sterile physiological saline. They were then placed in glass tubes containing $5 \mathrm{~mL}$ of sterile physiological saline, sonicated 
at $40 \mathrm{kHz}$ for $8 \mathrm{~min}$ (or $36 \mathrm{kHz}$ for $10 \mathrm{~min}$ ) and vortexed for $10 \mathrm{~s}$ (21). This procedure releases viable bacteria adhering to the coupons into the physiological saline. To quantify viable cells, bacteria were resuspended, serially diluted 10-fold with sterilized physiological saline and cultured in trypticase soy agar at $37^{\circ} \mathrm{C}$ for 24-48h (21).

The experiment was repeated three times for each strain, and the mean and standard deviation were calculated.

\section{Activities of the tested disinfectants against the planktonic cells}

A $0.05 \mathrm{~mL}$ aliquot of $10^{8} \mathrm{CFU} / \mathrm{mL}$ suspension prepared as described above was added to glass tubes containing separately $4.95 \mathrm{~mL}$ of each tested disinfectant at $25^{\circ} \mathrm{C} \pm 2^{\circ} \mathrm{C}$ and vortexed for about 10 s. A positive control was performed by adding a $0.05 \mathrm{~mL}$ aliquot of the suspension $\left(10^{8} \mathrm{CFU} / \mathrm{mL}\right)$ to a glass tube containing $4.95 \mathrm{~mL}$ of sterile physiological saline. From each tube, $0.5 \mathrm{~mL}$ was sampled after $10 \mathrm{~min}$, added to $4.5 \mathrm{~mL}$ of Letheen Broth (11) to inactivate the disinfectants for $10 \mathrm{~min}$, and vortexed again for 10s. Viable cells were counted as described above. The experiment was performed three times for each strain, and the mean and standard deviation were calculated (21).

\section{Scanning electron microscopy observations}

After treatment with the tested disinfectants, the stainless steel coupons were immersed in $2.5 \%$ glutaraldehyde in $0.1 \mathrm{M}$ phosphate buffer ( $\mathrm{pH}$ 7.1) to fix the microorganisms, dehydrated in aqueous solutions of ethanol $(15,30,50,70,95$ and 100\%) for $15 \mathrm{~min}$, and dried in a centrifuge under vacuum, then coated with gold and examined under the scanning electron microscope JEOLJSM [T330A](25).

\section{Statistical analysis}

Numbers of $\mathrm{CFU} / \mathrm{cm}^{2}$ and $\mathrm{CFU} / \mathrm{mL}$ were transformed to $\log _{10}$. The data were analyzed by analysis of variance (ANOVA) and the Tukey multiple comparison test using MINITAB Statistical Software (version 13.1). Statistical significance was defined as $\mathrm{p}<0.05$.

\section{RESULTS AND DISCUSSION}

Poor sanitation of food contact surfaces, equipment, and processing environments has been a contributing factor in foodborne disease outbreaks $(5,8)$. In this study, we have demonstrated the efficacy of disinfectants used in food industries against foodborne pathogens in suspension and in biofilm. Table 1 shows the activities of the tested disinfectants on biofilm cells of $S$. aureus, L. monocytogenes and E. coli. The number of viable cells is presented as a logarithm. Statistically significant differences $(p<0.05)$ were found on average count of viable cells of all studied strains after treatment with the disinfectants.

Table 1. Effect of disinfectants on biofilm cells after treatment for 10 minutes

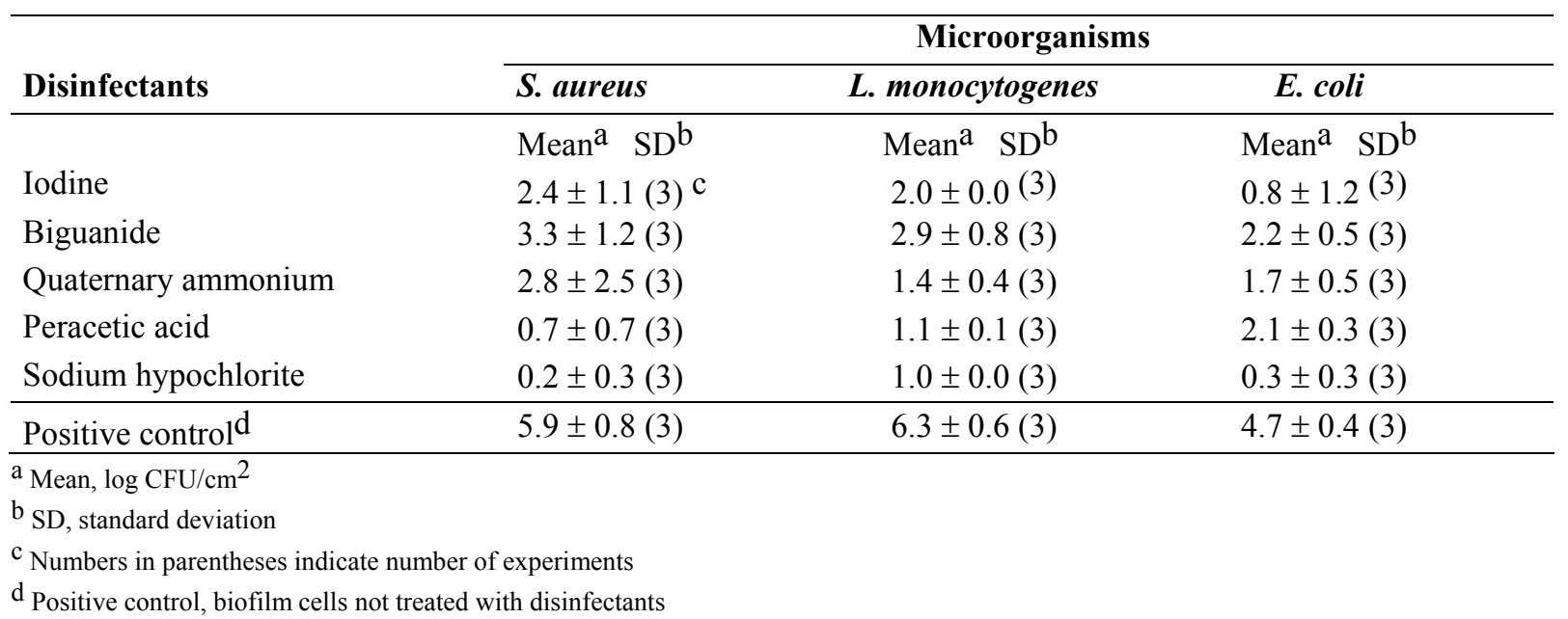


When compared with the positive control (5.9 $\left.\log \mathrm{CFU} / \mathrm{cm}^{2}\right)$, the numbers of viable cells of $S$. aureus biofilm were significantly reduced after treatments with sodium hypochlorite $(0.2$ log $\left.\mathrm{CFU} / \mathrm{cm}^{2}\right)$ and peracetic acid $\left(0.7 \log \mathrm{CFU} / \mathrm{cm}^{2}\right)$. After treatment with biguanide, the numbers of viable cells of $S$. aureus biofilm (3.3 $\log \mathrm{CFU} / \mathrm{cm}^{2}$ ) were higher than after treatment with all other tested disinfectants, following the quaternary ammonium compounds $\left(2.8 \log \mathrm{CFU} / \mathrm{cm}^{2}\right)$ and iodine $\left(2.4 \log \mathrm{CFU} / \mathrm{cm}^{2}\right)$. These data show that sodium hypochlorite was the most effective against $S$. aureus biofilm cells, while the biguanide disinfectant was the least effective.

Similar results were observed for L. monocytogenes biofilm cells. Compared with the positive control $\left(6.2 \log \mathrm{CFU} / \mathrm{cm}^{2}\right)$, the biguanide disinfectant $\left(2.9 \log \mathrm{CFU} / \mathrm{cm}^{2}\right)$ was the least effective in eliminating L. monocytogenes biofilm cells than all tested disinfectants, following iodine $\left(2.0 \mathrm{log} \mathrm{CFU} / \mathrm{cm}^{2}\right)$ and quaternary ammonium compounds $\left(1.4 \log \mathrm{CFU} / \mathrm{cm}^{2}\right)$. The numbers of viable cells of $L$. monocytogenes biofilm were lower after treatment with peracetic acid $\left(1.1 \log \mathrm{CFU} / \mathrm{cm}^{2}\right)$ and sodium hypochlorite $(1.0$ $\log \mathrm{CFU} / \mathrm{cm}^{2}$ ), showing that these disinfectants were the most effective against $L$. monocytogenes biofilm cells.

In the case of $E$. coli biofilm cells, low numbers of viable cells were obtained after treatment with sodium hypochlorite $(0.3$ $\left.\log \mathrm{CFU} / \mathrm{cm}^{2}\right)$ and iodine $\left(0.8 \log \mathrm{CFU} / \mathrm{cm}^{2}\right)$, when compared with the positive control $\left(4.7 \log \mathrm{CFU} / \mathrm{cm}^{2}\right)$. These data show that sodium hypochlorite and iodine were the most effective against $E$. coli biofilm cells. The count of viable cells after treatment with biguanide $\left(2.2 \log \mathrm{CFU} / \mathrm{cm}^{2}\right.$ ) reveals that this disinfectant was the least effective in eliminating $E$. coli biofilm cells, following peracetic acid $\left(2.1 \log \mathrm{CFU} / \mathrm{cm}^{2}\right)$ and quaternary ammonium compounds (1.7 log CFU/ $\left.\mathrm{cm}^{2}\right)$.

The activities of the tested disinfectants on planktonic cells of L. monocytogenes, S. aureus and E. coli are represented in Table 2. The number of viable cells is presented as a logarithm.

Table 2. Effect of disinfectants on the planktonic cells after treatment for 10 minutes

\begin{tabular}{llll}
\hline \multirow{2}{*}{ Disinfectants } & \multicolumn{3}{c}{ Microorganisms } \\
\cline { 2 - 4 } & S. aureus & L. monocytogenes & E. coli \\
Iodine & Mean $^{\mathrm{a}} \mathrm{SD}^{\mathrm{b}}$ & Mean $^{\mathrm{a}} \mathrm{SD}^{\mathrm{b}}$ & Mean $^{\mathrm{a}} \mathrm{SD}^{\mathrm{b}}$ \\
Biguanide & $0 \pm 0(3) \mathrm{c}$ & $0 \pm 0(3)$ & $0 \pm 0(3)$ \\
Quaternary ammonium & $0 \pm 0(3)$ & $0 \pm 0(3)$ & $0 \pm 0(3)$ \\
Peracetic acid & $0 \pm 0(3)$ & $0 \pm 0(3)$ & $0 \pm 0(3)$ \\
Sodium hypochlorite & $0 \pm 0(3)$ & $0 \pm 0(3)$ & $0 \pm 0(3)$ \\
\hline Positive control & $0 \pm 0(3)$ & $0 \pm 0(3)$ & $0 \pm 0(3)$ \\
\hline${ }^{\mathrm{a}}{ }_{\text {Mean, log CFU/cm }}^{2}$ & $5.4 \pm 0, .1(3)$ & $5.6 \pm 0.1(3)$ & $5, .6 \pm 0.2(3)$ \\
${ }^{\mathrm{b}}$ SD, standard deviation & & \\
${ }^{\mathrm{c}}$ Numbers in parentheses indicate number of experiments & & \\
$\mathrm{d}_{\text {Positive control, biofilm cells not treated with disinfectants }}$ & &
\end{tabular}

The results show that all the studied strains exhibited a significant decrease of the survival rate of viable cells after treatment with tested disinfectants. No growth was detected after $10 \mathrm{~min}$ of exposure to iodine $(0.20 \%)$, biguanide $(0.50 \%)$, quaternary ammonium compounds $(0.50 \%)$, peracetic acid $(0.50 \%)$ and sodium hypochlorite $(1.50 \%)$. These results, when compared with those presented in Table 1, show that biofilm cells are more difficult to be eliminated with chemical cleaning agents than planktonic cells in suspension. Our results coincide with those of other researchers who suggested that current sanitation practices are less effective on attached microorganisms compared to free living (planktonic) microorganisms. Schwach and Zottola (26) used electron microscopy to show that microorganisms were not completely 
removed from stainless steel by rinsing with up to $150 \mathrm{ppm}$ sodium hypochlorite. While they did not determine the viability of the remaining cells, their findings did not rule out the possibility that viable cells remained. Marques et al. (18) evaluated the efficiency of sodium dichloroisocyanurate, hydrogen peroxide and peracetic acid in inactivating Staphylococcus aureus cells adhered on stainless steel and glass surfaces. This researchers comproved that peracetic acid was the most efficient in removing adhered cells. Frank and Koffi (12) showed that a biofilm composed completely of L. monocytogenes on glass survived more than 10 times longer than free-living cells when exposed to anionic acid sanitizers. Similarly, Andrade et al. (2) demonstrated that Enterococcus faecium cells adhering to stainless steel were more resistant to chemical sanitizers than non-adherent cells. Trachoo and Frank (30) determined the survival of Campylobacter jejuni in mixed-culture biofilms grown on polyvinyl chloride (PVC) plastic coupons after treatment with chemical sanitizers. They showed that chlorine was the most effective sanitizer since it completely inactivated $C$. jejuni in the biofilms after treatment at $50 \mathrm{ppm}$ for 45s while quaternary ammonia, peracetic acid and a peracetic acid/peroctanoic acid mixture at 50 and $200 \mathrm{ppm}$ for $45 \mathrm{~s}$ not completely inactivated $C$. jejuni in the biofilms.

It may be difficult to compare results from these different studies because the conditions for attachment and biofilm development vary greatly and these differences can be significant (5).

Once the microorganisms have attached, they must be capable of withstanding normal disinfection processes. Biofilm bacteria display a resistance to biocides that may be considered stunning (15).

According to Characklis and Marshall (7), incomplete removal of the biofilm will allow it to quickly return to its equilibrium state, causing a rebound in total place counts following sanitization. Surviving organisms rapidly create more extracellular polymers as a protective response to irritation by chemical cleaning agents.

It has become clear that biofilm-grown cells express properties distinct from planktonic cells, one of which is an increased resistance to antimicrobial agents (17). Studies have indicated that slow growth and/or induction of an rpo $S$-mediated stress response could contribute to biocide resistance $(13,16)$. Adams and Mc Lean (1) reported that deletion of rpo $S$ greatly reduces the ability of $E$. coli to grow in biofilm yet has little effect on the growth of planktonic bacteria. The physical and/or chemical structure of exopolysaccharides or other aspects of biofilm architecture could also confer resistance by exclusion of biocides from the bacterial community. Finally, biofilm-grown bacteria might develop a biofilm-specific biocide-resistant phenotype (5, 17).

The microbiological evaluations observed using scanning electron microscope showed bacterial adherence and/or biofilm formation on stainless steel surface before and after treatment with studied disinfectants to strains: S. aureus (Figs 1a-f), E. coli (Figs 2a-f) and L. monocytogenes (Figs 3 a-f).

Results of this study indicate that biofilm cells are more resistant to chemical cleaning agents when compared with planktonic cells in suspension. Sodium hypochlorite seems to be the best chemical agent to eliminate biofilm cells formed on stainless steel surfaces, while biguanide seems to be the worst.

Additional studies should be performed to further elucidate how and why bacteria growing in complex surface-attached communities can protect themselves from the action of antimicrobial agents.

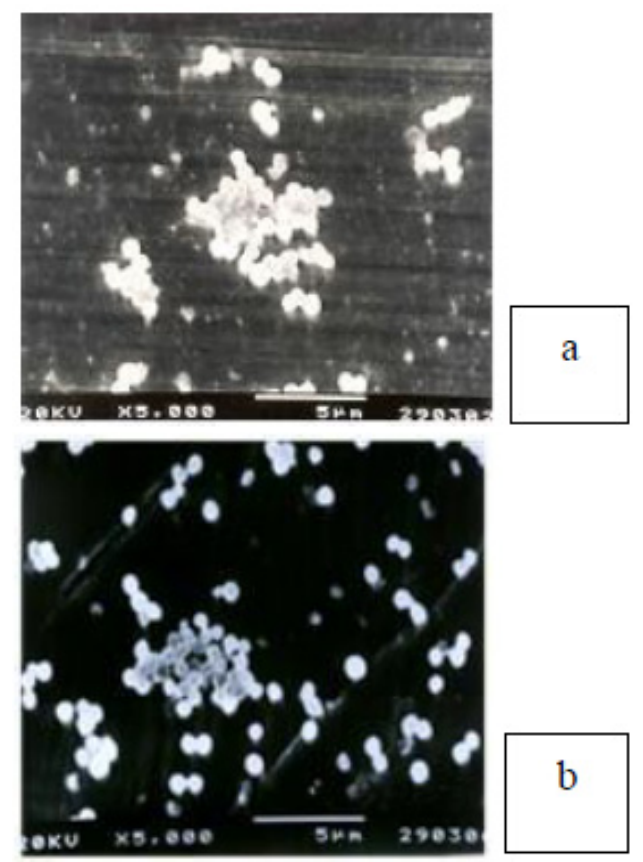



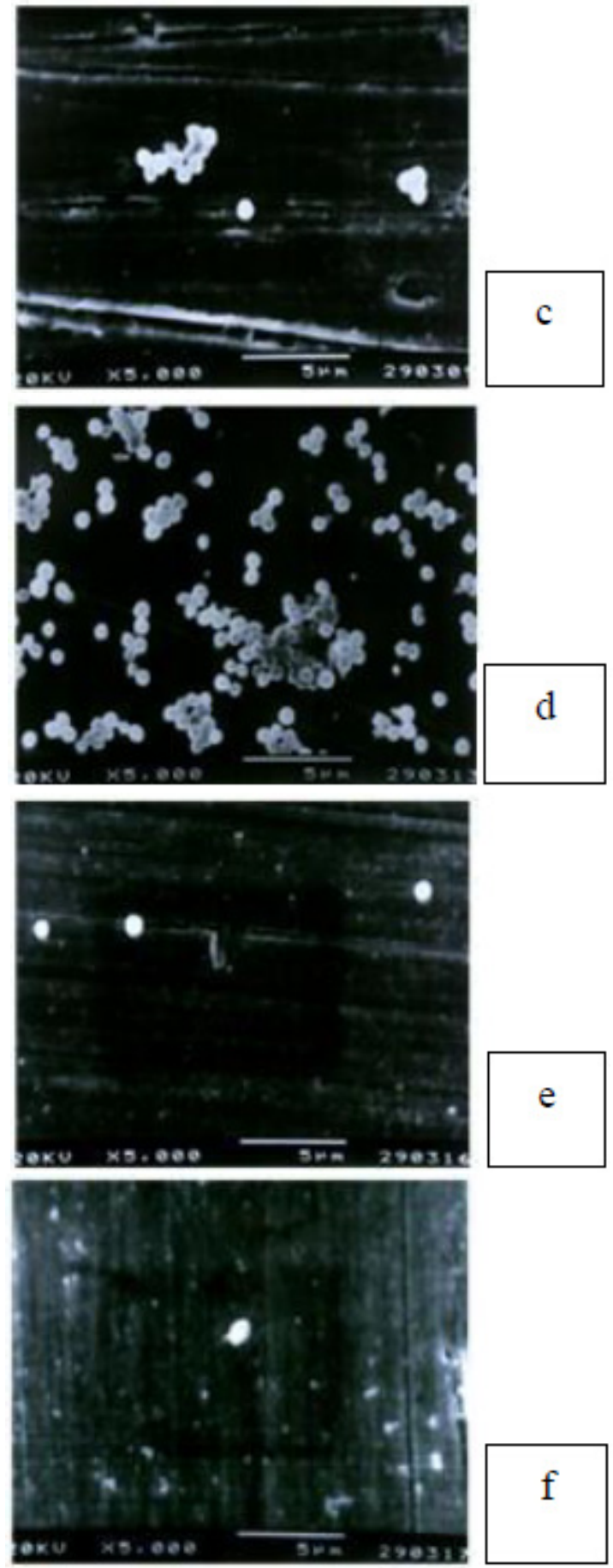

Figure 1. Scanning electron micrograph of $S$. aureus biofilm on stainless steel surface (x5.000) JEOL-JSM T330A: (a) before treatment with disinfectants; (b) after treatment with iodine disinfectant; (c) after treatment with biguanide disinfectant; (d) after treatment with quaternary ammonium compounds disinfectant, (e) after treatment with peracetic acid disinfectant and (f) after treatment with sodium hipochlorite disinfectant.
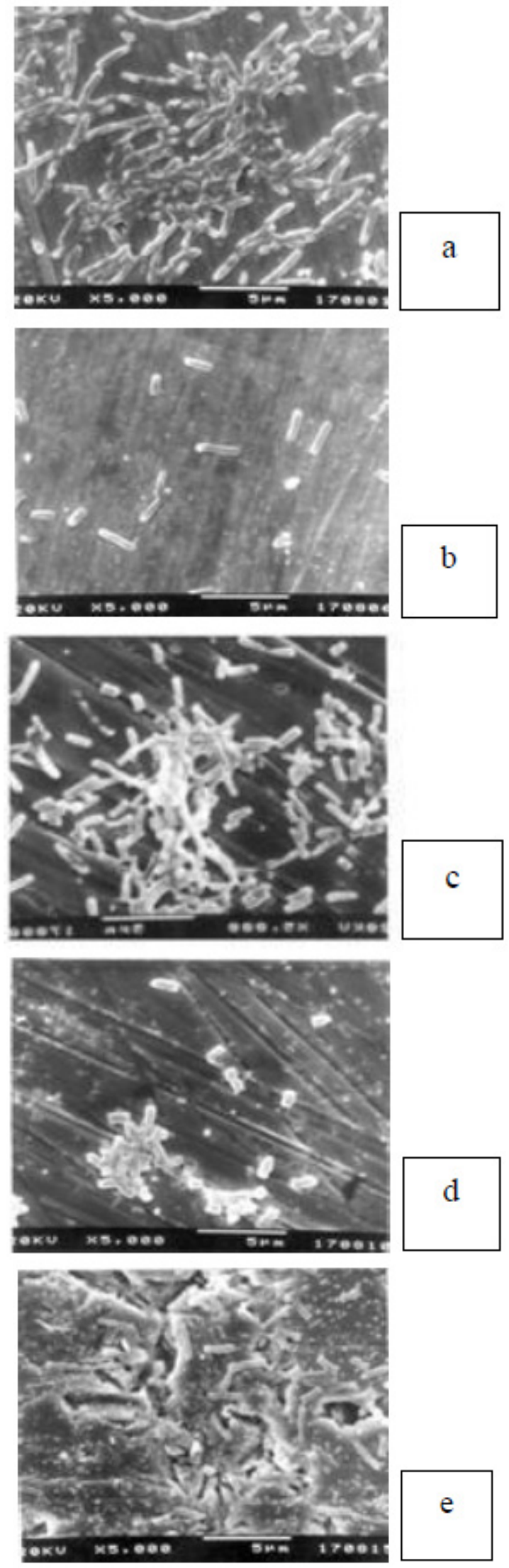


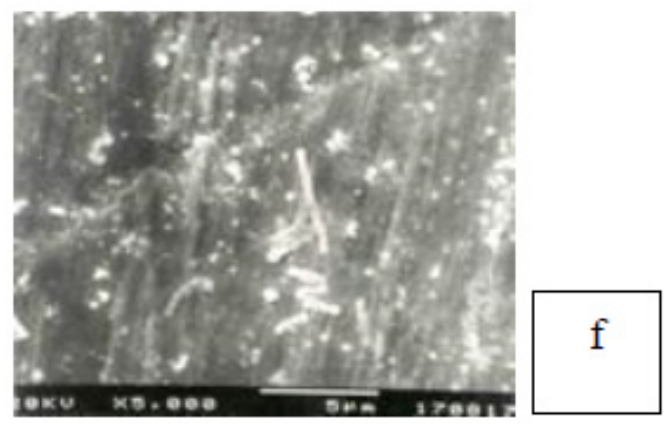

Figure 2. Scanning electron micrograph of E. coli biofilm on stainless steel surface (x5.000) JEOL-JSM T330A: (a) before treatment with 294 disinfectants; (b) after treatment with iodine disinfectant; (c) after treatment with biguanide disinfectant; (d) after treatment with quaternary ammonium compounds disinfectant, (e) after treatment with peracetic acid disinfectant and (f) after treatment with sodium hipochlorite disinfectant.
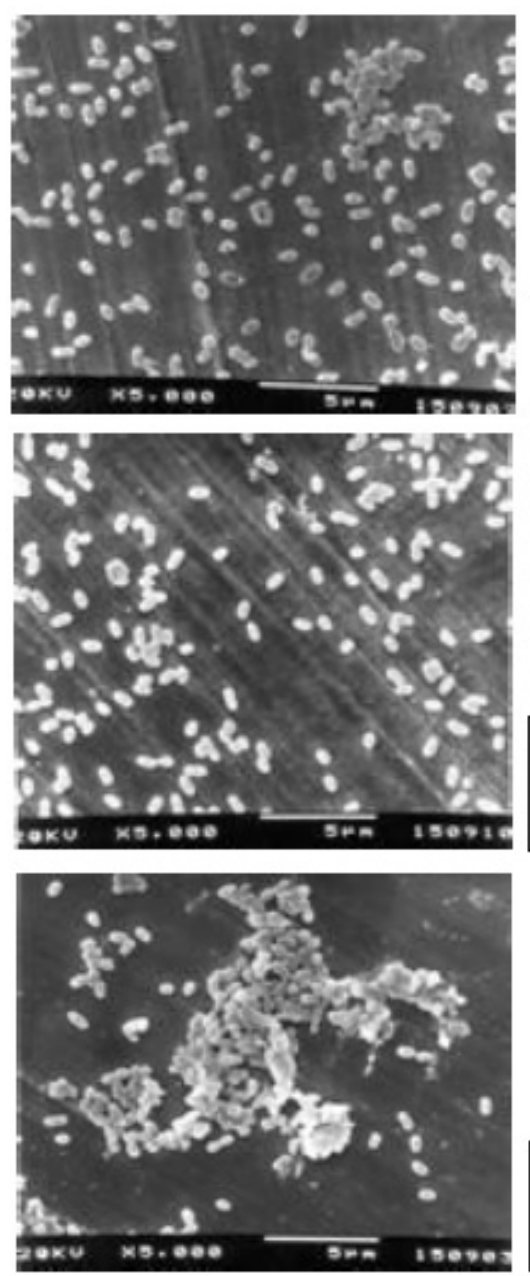
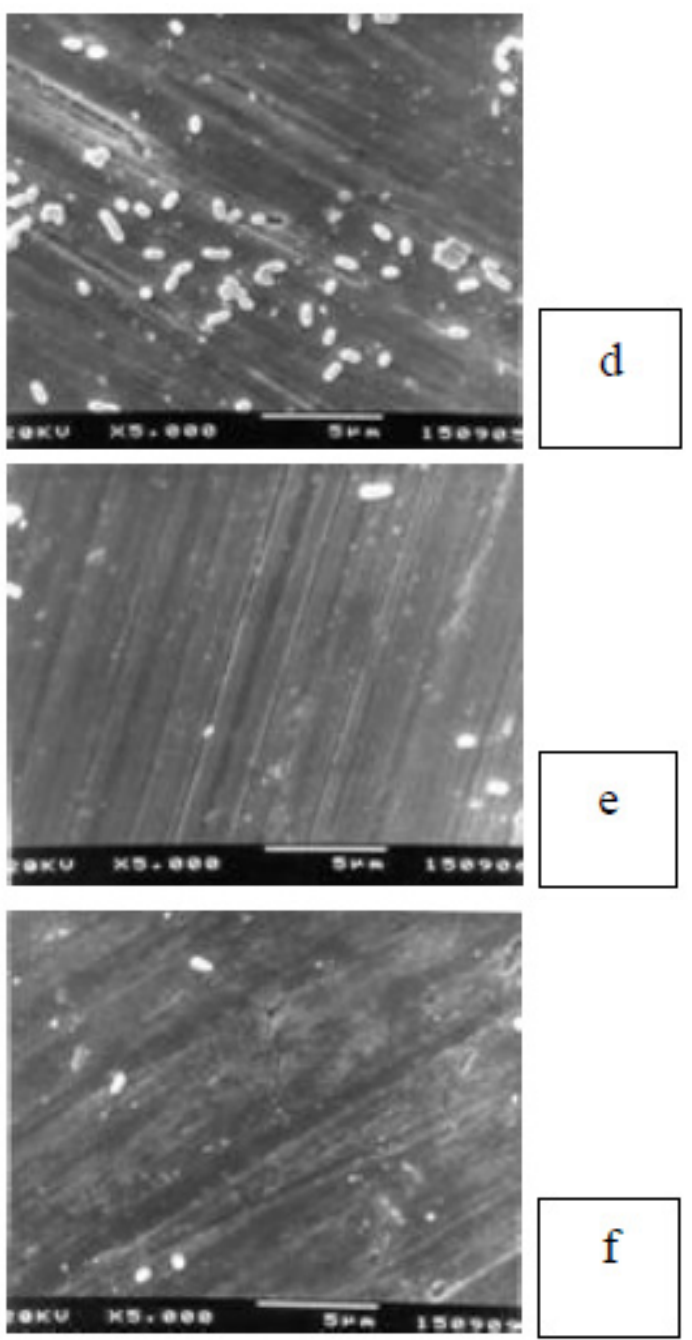

Figure 3. Scanning electron micrograph of L. monocytogenes biofilm on stainless steel surface (x5.000) JEOL-JSM T330A: (a) before treatment with disinfectants; (b) after treatment with iodine disinfectant; (c) after treatment with biguanide disinfectant; (d) after treatment with quaternary ammonium compounds disinfectant, (e) after treatment with peracetic acid disinfectant and (f) after treatment with sodium hipochlorite disinfectant.

\section{ACKNOWLEDGEMENTS}

This work was supported by The Diagnostic Centre at the Community Assistance Nucleus - NAC - UNESP - Sao Paulo State University, School of Pharmaceutical Sciences, Araraquara, Sao Paulo, Brazil 


\section{REFERENCES}

1. Adams, J.L.; Mc Lean, R.J.C. (1999). Impact of rpoS deletion on Escherichia coli biofilms. Appl. Environ. Microbiol, v. 65 (9), $4285-$ 4287.

2. Andrade, N.J.; Bridgeman, T.A.; Zottola, E.A. (1998). Bacteriocidal activity of sanitizers against Enterococcus faecium attached to stainless steel as determined by plate count and impedance methods. J. Food. Prot, v. 61(7), 833-838.

3. Bagge, D.; Hjelm, M.; Johansen, C.; Huber, I.; Gram, L. (2001). Shewanella putrefaciens adhesion and biofilm formation on food processing surfaces. Appl. Environ. Microbiol, v.67 (5), 2319-2325.

4. Beresford, M.R.; Andrew, P.W.; Shama, G. (2001). Listeria monocytogenes adheres to many materials found in food-processing environments. J. Appl. Microbiol, v.90 (6), 1000-1005.

5. Cabeça, T.K.; Pizzolitto, A.C.; Pizzolitto, E.L. (2006). Assessment of action of disinfectants against Listeria monocytogenes biofilms. Alim. Nutr, v. 17 (2), 121-125.

6. Campanac, C.; Pineau, L.; Payard, A.; Baziard-Mouysset, G.; Roques, C. (2002). Interaction between biocide cationic agents and bacterial biofilms. J. Antimicrob. Agents. Chem, v.46 (5), 1469-1474.

7. Charachlis, W.G.; Marshall, K.C. (1990) Biofilms, New York: WileyIntercience, 796p.

8. Chmielewski, R.A.N.; Frank, J.F. (2003). Biofilm formation and control in food processing facilities. Inst. Food. Technol, v.2 (1), 22-32.

9. Corning Incorporated - Corning, New York, 14831, [on line] Available at: http://www. Scienceproducts.corning.com

10. Costerton, J.W. Introduction to biofilm. (1999). Intern. J. Antimicrob. Agents, v.11 (3), 217-221.

11. Difco Manual of Dehydrated Culture Media and Reagents for Microbiology. Difco Laboratories, Detroit, 1984, 1155p.

12. Frank, J.H.; Koffi, R. (1990). A surface-adherent growth of Listeria monocytogenes is associated with increased resistance to surfactant sanitizers and heat. J. Food. Protect, v.53 (7), 550-554.

13. Gilbert, P.; Das, J.R.; Jones., M.V.; Allison, D.G. (2001). Assessment of resistance towards biocides following the attachment of micro-organisms to, and growth on, surfaces. J. Appl. Microbiol, v. 91 (2), 248-254.

14. Hood, S.K.; Zottola, E.A. (1995). Biofilms in food processing. Food Control, v. 6 (1), 9-18.

15. Le Chevalier, M.W.; Cawthon, C.D.; Lee, R.G. (1988). Factor promoting survival of bacteria in chlorinated water supplies. Appl. Environ. Microbiol, v.54 (3), 649-654.

16. Liu, X.; Ng, C.; Ferenci, T. (2000). Global adaptations resulting from high population densities in Escherichia coli cultures. J. Bacteriol, v.182 (15), 4158-4164.
17. Mah, T.H.C.; O'toole, G.A. (2001). Mechanisms of biofilm resistence to antimicrobial agents. Trends Microbiol, v.9 (1), 34-39.

18. Marques, S.C.M.; Rezende, J.G.O.S.; Alves, L.A.F.; Silva, B.C.; Alves, E.; Abreu, L.R.; Piccoli, R.H. (2007). Formation of biofilms by Staphylococcus aureus on stainless steel and glass surfaces and its resistance to some selected chemical sanitizers. Braz. J. Microbiol, v. 38(3), 538-543.

19. Meads, P.S.; Slutsker, L.; Dietz, U.; Mc Caig, L.F.; Bresee, J.S.; Shapiro, C.; Griffin, P.M.; Tauxe, R.V. (1999). Food-related illness and death in the United States. Emerg. Infect. Dis, v.5 (5), 607-625.

20. Mittelman, M.W. (1998). Structure and functional characteristics of bacterial biofilms in fluid processing operations. J. Dairy. Sci, v.81(10), 2760-2764.

21. Miyano, N.; Oie, S.; Kamiya, A. (2003). Efficacy of disinfectants and hot water against biofilm cells of Burkholderia cepacia. Biol. Pharm. Bull, v.26 (5), 671-674.

22. Montville, R.; Schaffner, D.W. (2003). Inoculum size influences bacterial cross contamination between surfaces. Appl. Environ. Microbiol, v.69 (12), 7188-7193.

23. Norwood, D.E.; Gilmour, A. (1999). Adherence of Listeria monocytogenes strains to stainless steel coupons. J. Appl. Microbiol, v.86 (4), 576-582.

24. Oliveira, M.M.M.; Brugnera, D.F.; Alves, E.; Piccoli, R.H. (2010). Biofilm formation by Listeria monocytogenes on stainless steel surface and biotransfer potential. Braz. J. Microbiol, v. 41(1), 97-106.

25. Pizzolitto, E.L.; Pizzolitto, A.C.; Pozetti, G.L. (2001). Chemical and microbiological evaluation of the internal surfaces of aluminum tubes both unlined and lined with epoxi resin by means of the stereoscope and scanning electron microscope. Braz. J. Microbiol, v.32 (4), 340-344.

26. Schwach, T.S.; Zottola, E.A. (1984). Scanning electron microscopic study on some effects of sodium hypochlorite on attachment of bacteria to stainless steel. J. Food. Prot, v.47 (10), 756-759.

27. Sinde, E.; Carballo, J. (2000). Attachment of Salmonella spp. and Listeria monocytogenes to stainless steel, rubber and polytetrafluorethylene: the influence of free energy and the effect of commercial sanitizers. Food. Microbiol, v.17 (4), 439-447.

28. Tauxe, R.V. (1997). Emerging foodborne diseases: an evolving public health challenge. Emerg. Infect. Dis, v.3 (4), 425-434.

29. Trachoo, N. (2003). Biofilms and the food industry. Songklanakarin J. SCI.Technol, v.25 (6), 807-815.

30. Trachoo, N.; Frank, J.F. (2002). Effectiveness of chemical sanitizers against Campylobacter jejuni - containing biofilms. J. Food. Prot, v. 65 (7), 1117-1121.

31. Wong, A.C.L. (1998). Biofilms in food processing environments. J. Dairy. Sci, v.81 (10), 2765-2770. 